\title{
Humiliating the Brazilian poor
}

\section{The iconoclasm of former president Lula}

\section{ERIK BÄHRE \&} FABÍOLA GOMES

Erik Bähre is an associate professor at the Institute of Cultural Anthropology and Development Sociology, Leiden University, The Netherlands. His research interests include economic anthropology, conflict studies and care arrangements. His email is ebaehre@fsw. leidenuniv.nl.

Fabiola Gomes is a

postdoctoral researcher at the Department of Anthropology, University of Brasilia, Brazil. Her areas of research include marriage, kinship, premarital romance, healthcare and insurance. Her email is fabis.gomes@hotmail.com.
'Unfortunately we weren't lucky that day and it didn't happen to Lula', Roberto told us. Roberto is a successful businessman who sells insurance policies from his office in Brasília. The lack of luck he is referring to concerns a helicopter crash that took place in São Paulo in 2015. Five people died in the crash, including Thomaz Alckmin, the son of São Paulo's governor, Geraldo Alckmin. Roberto is very straightforward about his views: 'Thomaz Alckmin had nothing to do with this' (suggesting that Thomaz Alckmin did not play a role in the political conflicts his father has been involved in). Roberto goes on to argue that former president Luiz Inácio Lula da Silva is not so innocent however, and that he is the one who should have been on that fatal flight. Roberto alleges that the helicopter belonged to one of Brazil's largest financial service companies. The company always invited President Lula to spend New Year's Eve on a company-owned island off the coast of São Paulo and what Roberto finds unfortunate is that although Lula regularly took that same helicopter, it never crashed when he was a passenger.

The contention between Alckmin and Lula goes a long way back. In addition to having once been the governor of São Paulo, Geraldo Alckmin is currently the leader of PSDB, the Brazilian Social Democracy Party. In 2006, he unsuccessfully ran for president against the incumbent president, Lula, and is running again in this year's presidential elections. Lula, who was Brazil's president from 2003 to 2011 for PT, the Worker's Party, is also running in the October elections, although his candidacy hangs in the balance. In July 2017, Lula was convicted of corruption and money laundering in relation to receiving a seaside apartment worth over half a million pounds from a construction company. In January 2018, Lula lost his first appeal and was sentenced to 12 years' imprisonment. In April, the Supreme Court ruled that he would have to await his second appeal in jail. Because Lula is in prison, it is yet to be decided if he can officially campaign for October's elections.

Lula's PT and Alckmin's PSDB parties are bitter political rivals and Roberto's account of the helicopter crash clearly reveals where his political allegiances lie. Roberto is a friendly and helpful man. When we met him in his office, he offered us coffee and water and made sure we felt comfortable and welcome. His tone of voice was friendly, despite conveying a strong message. We were struck by the level of aggression in his account of the helicopter crash. For Roberto, it is not enough for Lula to have been convicted of corruption: Roberto actually thinks it a shame that Lula was not on that fatal flight. Roberto's hostility is not uncommon. At political protests against PT, some protesters wear masks depicting Lula as a zombie with white skin and hair and blood running out of his mouth. On the forehead of the mask there is a circle resembling a shooting target inscribed with the words 'FORA ZUMBI', meaning 'get out zombie'. The protesters want the undead gone.

\section{Lula and the poor}

At these protests, in conversations and especially on social media (WhatsApp, Instagram and Facebook), we came across many vicious attacks against Lula. Where does this aggression come from and what are these attacks about? Why is it that Lula has been given an almost iconic status around which such aggression crystallizes? We believe these attacks do not simply reflect people's hatred towards corruption. We argue that the memes not only reveal class subjectivities and identities, but also construct these by dehumanizing the poor. The memes and their surrounding conversations do not identify which class positions the people posting them associate themselves with. Instead, they use ridicule to point out which positions they definitely do not associate with - namely, the poor or previously poor population that Lula represents. The international anti-corruption discourse (nobody will argue that corruption is permissible) legitimizes expressions of hatred towards Lula and the criminalization of the poor people he represents.

It is well known that Lula grew up in poverty. His parents were sharecroppers in Pernambuco, a Northeastern state of Brazil, before migrating to São Paulo in the 1950s. From an early age, Lula supplemented his family's income by working as a shoeshiner, street vendor and then factory worker. The conditions in which he grew up meant that he had little formal education. And yet, it was Lula's background that was decisive in winning him the presidency, because it garnered the political support of those Brazilians who, just like him, lived in poverty.

Lula's ascension to the highest position in the country was a watershed moment. The office of the presidency had always been held by the country's elite. The president before Lula, Fernando Henrique Cardoso, was an important intellectual with a well-established academic career. Brazilian presidents had typically come from influential families who could trace their genealogy back to Portuguese and other European ancestors who came to Brazil during the colonial period or in the migration waves from Europe. Some of them belonged to what we now might call the 1 per cent, a privileged class with capital invested in the country's natural resources. In sharp contrast, Lula's parents did not even have their own land to work on. Thus, in 2003, when this landless former shoeshiner became president, he represented anything but Brazil's political elite. And when Lula ended his second term in office in 2010, his approval rating was around 80 per cent, a record for a Brazilian president. ${ }^{1}$

We argue that class is an important theme in the images circulating on Facebook, Instagram and WhatsApp. Minutes after Lula lost his first appeal in January, and after the Supreme Court ruled his imprisonment in April, images appeared showing Lula drunk on Cachaça 51, a cheap brand of spirit made of sugar cane that is typically drunk by lower-class men (farm workers, factory workers, the unemployed). We will show other memes that portray Lula as uneducated and illiterate to the extent that he appears unable to write a simple sentence without making several mistakes. The memes further suggest that Lula's home is prison, to which he should return, and other memes use the cultural trope of rags to riches to mock him.

How to interpret the representation of class found in these memes? What do the memes and their related conversations reveal about the experiences of people in Brazil? The people who circulate these memes on Facebook, Instagram and WhatsApp are diverse. The members of the social media groups we looked at in our research included professionals (lawyers, dentists, medical doctors, physiotherapists), civil servants, housewives, schoolteachers and police officers. They neither vote for nor feel represented by Lula and PT, but instead support Lula's right-wing rival, Jair Bolsonaro. Many of them 
Fig. 1. Social media post: 'Instituto Lula' ${ }^{3}$

Fig. 2. Social media post: 'Lula writing at his desk'. probably self-identify with the equivocal term 'middle class' (more on this later), even though we know that some have quite precarious living conditions, while others have more comfortable and secure lives. But these differences become less relevant because the memes make a statement about what one is not - namely, the classe popular, or the 'popular class' that Lula and PT represent. How exactly do the memes establish this symbolic class distinction between 'us' and 'them', and what do 'us' and 'them' stand for in moral terms?

In A elite do atraso (The backward elite), Souza (2017) argues that aggression against the poor is what in fact lies behind the corruption scandal known as 'Operation Car Wash' and other allegations of corruption against Lula and PT politicians. Souza points out that the Brazilian elite and middle class have never before been concerned about corruption. Today's anger towards corruption, he argues, is part of what he defines as the anti-popular pact: a pact formed by the country's elite and middle class to protect their private power by defining the general population as inferior, as the ralé, or the masses, the plebs.

Souza (2017) argues that the contempt and hatred towards the 'popular class' justifies and protects elite privileges and fortifies Brazil's deep economic and racial inequalities. He argues that Lula has defied this anti-popular pact just by being who he is: a poor man who broke into the ranks of the political elite. He has challenged the pact in his speeches and policies, which place an emphasis on the respectability and humanity of the poor. Lula poses a threat to elitist privileges by resisting the ideological foundations of class inequality. To what extent can we recognize these dynamics in the circulation and support of memes that humiliate Lula?

We examine what Rose calls 'the site of the image itself' and 'the site where it is seen by audiences' (Rose 2001: 16). ${ }^{2}$ We are specifically interested in what Rose (2001) defines as the compositional and social modality of visual material. The compositional modality concerns the arrangement of the image as an object that can be disseminated. Key questions for analyzing the compositional modality of visual material are: what are the visual effects being used? What discourse does the image present and how is this discourse visualized? How does the image incorporate cultural tropes? The compositional modality, Rose (2001) points out, also examines how images relate to texts and other visual materials. In our case, these are comments on WhatsApp, Facebook and Instagram.

Rose defines social modality as the 'range of economic, social and political relations, institutions and practices that surround an image and through which it is seen and used' (Rose 2001: 17). The social modality focuses on why images surface at a particular moment: what is the saliency of these images in the current political and economic climate in Brazil? We will show that the social modality of the memes is related to a deep-seated political antagonism, extreme inequalities and at the same time, precarious class distinctions and competing discourses about what it means to be a moral person. We first examine the compositional modality of Lula's images and then analyze their social modality.

\section{Humiliations and iconoclasm}

The images are intended to humiliate Lula by referring to the stereotype of the 'irresponsible poor'. They depict him as an illiterate drunkard, unable to speak proper Portuguese. They tell a story of a man who undeservedly went from rags to riches, and now deserves to go back to rags again. Lula should 'go back home', i.e. the terrible conditions of prison.

The meme in Fig. 1 shows a prison, with the text 'Instituto Lula' placed on the roof. Instituto Lula has a
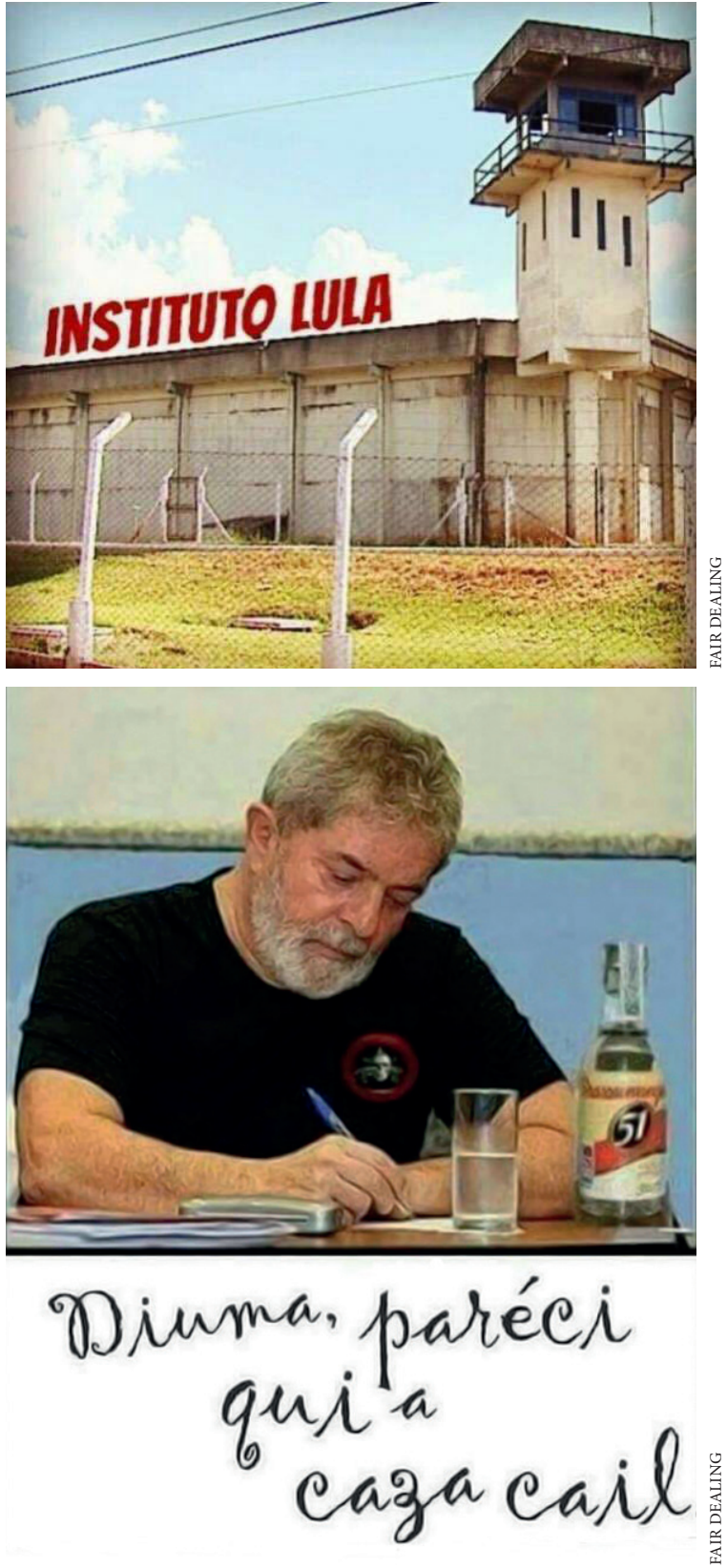

double meaning here. First, it implies that the prison is Lula's new home. This is where he belongs - not in politics, not as the country's president. Second, Instituto Lula refers to Lula's attempts to combat poverty. Established in 2005, the Lula Institute set out to develop policies and activities aimed at diminishing poverty in Latin America and Africa. The institute also works to preserve the history of social movements and their contribution to democracy and poverty alleviation. Therefore, calling the prison 'Instituto Lula' suggests that such efforts to alleviate poverty, strengthen democracy and remember the contributions of social movements also need to be incarcerated, and possibly even the poor themselves.

In Fig. 2, we see Lula writing a letter to Dilma. Dilma Rousseff (PT) was the president of Brazil from 2011 until her impeachment in $2016 .{ }^{4}$ The impeachment was highly controversial and many Brazilians liken it to a coup d' etat. In the meme, Lula writes: 'Dilma, the house fell'. This is a common expression in Brazil that means everything has 'gone south'. It is typically used when someone is caught doing something wrong, thus leading to the collapse of a scheme. Almost every single word in this short text is misspelt. Instead of Dilma, it reads 'Diuma'; instead of 'parece', it reads 'paréci'; instead of 'que', it reads 'qui'; instead of 'caiu', it reads 'cail'. Even the word for house (casa) is misspelt. The text clearly mocks Lula's 
low level of formal education. But it also makes fun of his Northeastern accent, which is typical of Brazil's poorest region. ${ }^{5}$ The phonetic way of writing shown in the meme expresses a linguistic prejudice against people from this impoverished region. His inferior class is further emphasized by the bottle of Cachaça 51, which has become an icon of the drinking lower classes, the irresponsible and the unemployed.

In Fig. 3, Lula is shown on the phone talking to Odebrecht, a construction company implicated in Operation Car Wash and part of the legal case against Lula. Lula says: 'Hello, is this Odebrecht? Good morning comrade, do you make tunnels?' Here, the meme mocks Lula's intelligence and his fight against Brazil's military dictatorship. The suggestion that Lula thinks Odebrecht can help him escape from prison is a commentary on favouritism in business and politics. In other words, because Lula helped this company, he can now ask for a favour in return. The criticism is that Lula will even resort to corruption to escape prison.

The word 'companheiro' suggests that Lula sees his relationship with Odebrecht as more than professional. 'Companheiro' is an expression that roughly translates as fellow or comrade. It was popularly used during Brazil's dictatorship when activists fighting the military regime would call one another by the codename 'companheiro' or 'companheira'. It is still used amongst union leaders and PT members. Here, the word implies that Lula and Odebrecht are comrades in corruption and suggests a link between corruption, political resistance, the struggle for better working conditions and leftism in general. In addition, the text is full of spelling errors that make Lula look stupid and uneducated: Odebrecht is misspelt as Odebréchi, companheiro (fellow) is misspelt as 'cumpanhêro', vocês (you plural) as 'ocêis', and fazem (make) as 'faiz'.

The meme in Fig. 4 was circulated well before Lula was imprisoned. It shows Lula and Sérgio Cabral, the former governor of the state of Rio de Janeiro, both dressed in orange prison uniforms. Sérgio Cabral belongs to the Brazilian Democratic Movement (MDB) political party and has been in jail since 2016, serving two prison sentences related to Operation Car Wash. He received a sentence of 14 years for corruption and money laundering and a sentence of 45 years for embezzlement.

In the meme, Lula leans towards Cabral and asks: 'Could you stay in my cell with me?' Cabral responds: 'I can't! I went to university'. Brazilian law stipulates that people with higher education degrees are allowed a special prison cell, meaning they do not have to share with people who do not have a university degree. This privilege lasts while the prisoner is appealing a conviction. Only after all appeals are exhausted does the prisoner go to an ordinary cell in the mainstream prison regime. This means that if two people are convicted of the same crime - which is not the case here - the person with a university degree is entitled to better prison conditions than the uneducated person. Thus, this meme once again mocks Lula's lack of formal education, emphasizing that even in prison he is not equal to the educated elite and middle class.

The meme in Fig. 5 draws a parallel between Lula's imprisonment in the 1980s and his current imprisonment for corruption. The first picture was taken in 1980 when Lula was arrested by the Departamento de Ordem Política e Social (DOPS), a police branch used by the military dictatorship to suppress any resistance against the regime. Lula, along with many others, was arrested and tortured by DOPS for anti-dictatorship activities. The second picture shows Lula today, and the caption reads: 'The good son returns home'. This meme had circulated before his first appeal and before the Supreme
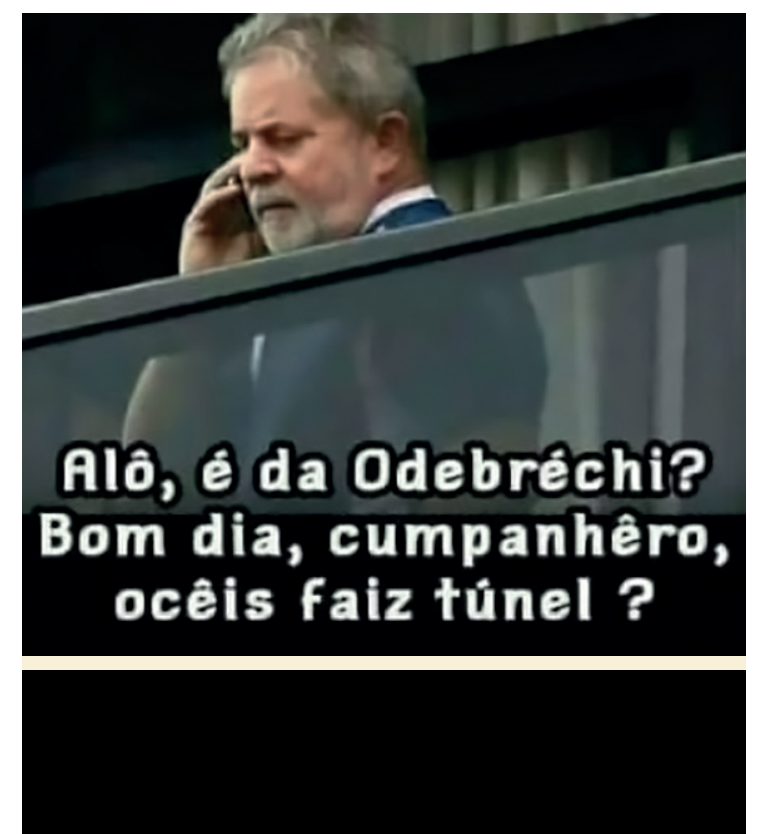

\section{VOCÊ FICA NA CELA COMIGO?}
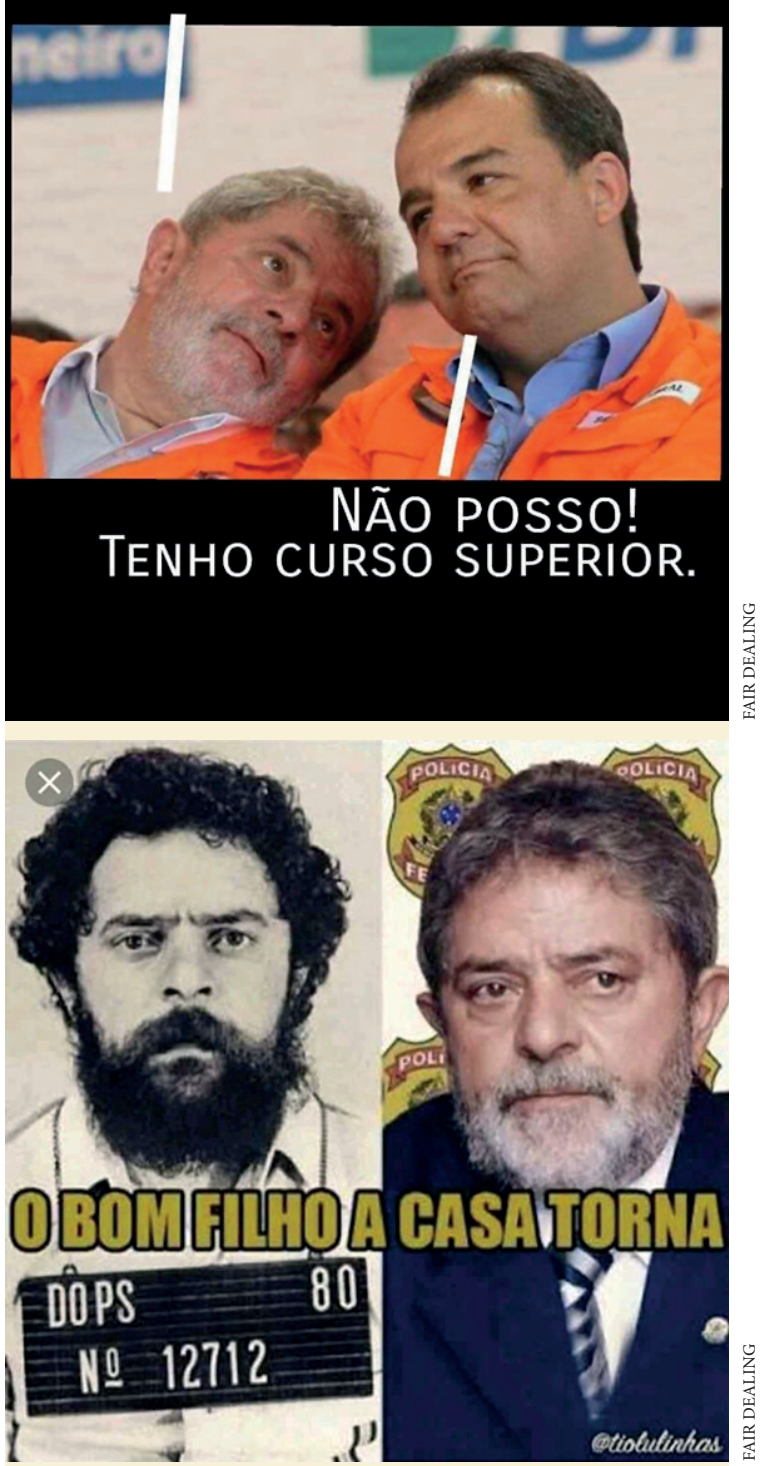

Fig. 3. Social media post: 'Lula calling Odebrecht'

Fig. 4. Social media post: 'Lula asking to share cell'.

Fig. 5. Social media post: 'Back home in prison'. 
Fig. 6. Social media

post: 'Lula with Moro and Bolsonaro'

Fig. 7. Social media post: 'Drinking like a convict'.

1. Source: Datafolha Research Institute. http:/ datafolha.folha.uol. com. br/opiniaopublica/ 2010/12/1211078-acima-dasexpectativas-lula-encerramandato-com-melhoravaliacao-da-historia.shtml. 2. Rose (2001) also points to the analysis of the production of images, but we do not examine this here.

3. To guarantee anonymity, we have omitted details that could identify the members of the social media group in which we participated that circulated and supported these memes.

4. See van Dijk (2017) on the manipulative strategies by right-wing media, especially Globo Corporation, to delegitimize and demonize Dilma and the PT.

5. This region has not always been poor, but its economic importance has changed throughout Brazil's economic history. When sugar cane production was surpassed by gold exploitation, the economy moved to central Brazil. That, along with industria development (1930-1945), made the Southeast region the richest, leading people from the Northeast to migrate looking for jobs in São Paulo, Minas Gerais, Rio de Janeiro and Brasília. Today's prejudice against Northeasterners comes, at least partially, from this migratory period when many poorly educated workers arrived in these urban areas. A popular discourse emerged in which the Northeast was seen as a place of the past. Nonetheless, the Northeast continues to contain an economic and political elite who wield national influence.

6. See Pinheiro-Machado \& Maia (2018).

7. This iconographic approach has been well developed for understanding how people's dreams, fantasies and anxieties are infused by global economic change (Bähre 2002

Comaroff \& Comaroff 1999 Meyer 2007; Taussig 1980; Thoden van Velzen 1997)

8. Growth rate based on GDP (gross domestic product). During this period, only in 2009 , the year after the global financial crisis there was a growth rate of -0.13 per cent. Based on World Bank national accounts data, and OECD national accounts data: https://data. worldbank.org/indicator/ NY.GDP.MKTP.KD.ZG?end= 2016\&locations $=$ BR\&start $=1$ 990\&view=chart;
Court decided that Lula should await the results of further appeals in prison.

Rather than pointing to corruption per se, this meme is more about criminalizing the struggle against a military dictatorship by equating it to the contestation of a convic:tion of corruption. 'Returning home' also has an important regional connotation. As mentioned earlier, Lula is from the poor Northeast region of Brazil, and class conflict is often talked of as a regional issue, where people from the wealthier South despise the poor Northeasterners. 'Returning home' here seems to suggest going back to the region of the poor.

Some memes give insight into the specific political alliances of Lula's attackers. In Fig. 6, we see a picture of a black man captured and paraded by the police. This is a common image in Brazilian sensationalist media. A photo of Lula's head is superimposed on the body of an alleged criminal. On one side, also superimposed, is the head of Sérgio Moro, the judge who is spearheading Operation Car Wash. Moro is a controversial figure who has made political statements, often against PT, to the media. On the other side is the superimposed head of Jair Bolsonaro. Although Bolsonaro is Lula's political opponent and also running for president, he has no role in prosecuting Lula. Bolsonaro is, however, known for vehemently condemning corruption in his speeches and for his extremist ideas. For example, he is in favour of torturing criminals and prisoners, is known for making numerous racist remarks in public and has even been convicted for telling a female politician he would not rape her because she was not worth raping.

Bolsonaro is not nearly as popular as Lula. Polls from the beginning of this year show that only about 15 per cent of the population intended to vote for him. However, his support has been increasing somewhat, and some analysts argue that if Lula is not allowed to run, Bolsonaro could become Brazil's next president (Lima et al. 2018). The people sharing this meme on social media were not only making a statement against the corruption personified by Lula and his opponent, Judge Moro, but also in favour of Bolsonaro. Furthermore, the fact that the prisoner in the meme is wearing white flip-flops is reference to his low social class.

Lula, captured by Moro and Bolsonaro, is shown as a poor black man under arrest and carelessly exposed to the media as a criminal. In addition to corruption, this meme is also about criminalizing the poor and supporting Lula's extremist opponent, Bolsonaro. It was posted by an Instagram account called 'policia motivacional', which posts information on how to apply for job opportunities with the police. The Instagram account has published several memes that support Bolsonaro, along with posts that say things like 'a good crook is a dead crook'

The meme in Fig. 7 shows Lula knocking back a shot of cachaça. His eyes suggest that he is already drunk. It says: 'Fuck man, today I'm gonna drink like a convict'. This is a common Portuguese expression, and here it has a double meaning. 'Drinking like a convict' means getting very drunk, but here it also refers to Lula being sent to jail. This meme also identifies the political affiliation of its creators. The logo in the picture is from the Movimento Brasil Livre (MBL), a very active movement known for its conservative right-wing political agenda promoting what it calls 'Christian family values'. It also organized the protests against Judith Butler when she visited Brazil in November last year. The protesters portrayed her as a witch, threatened her, accused her of spreading immoral and dangerous ideas that undermine family values and claimed that she had come to Brazil to promote paedophilia, among other things. This meme suggests that the Movimento Brasil Livre supports the message in the photo, policia_motivaciona

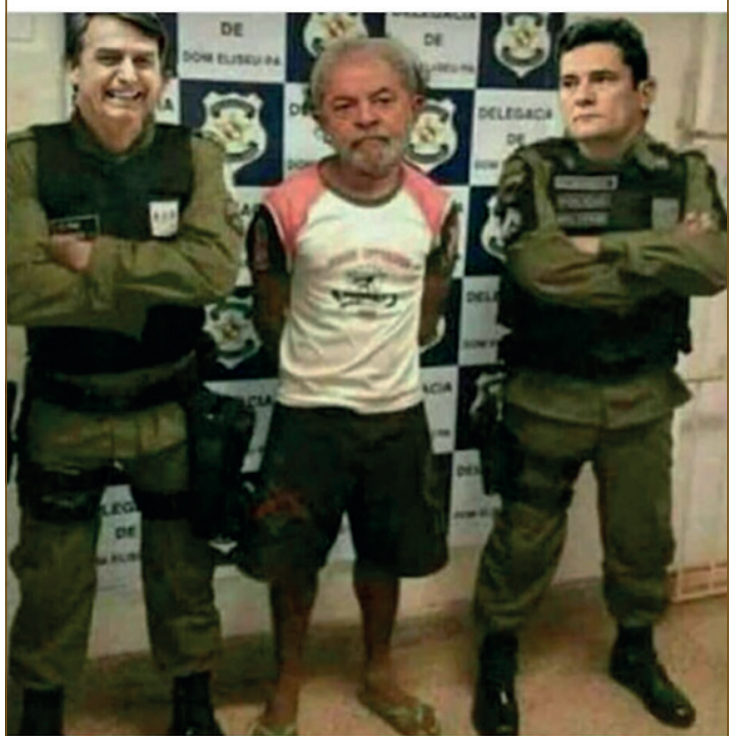

policia motivacional kkkkkkl. Por isso que pago internèt $\$ S$

\#operacionais \#deusnocomando \#forcaehonra.o0
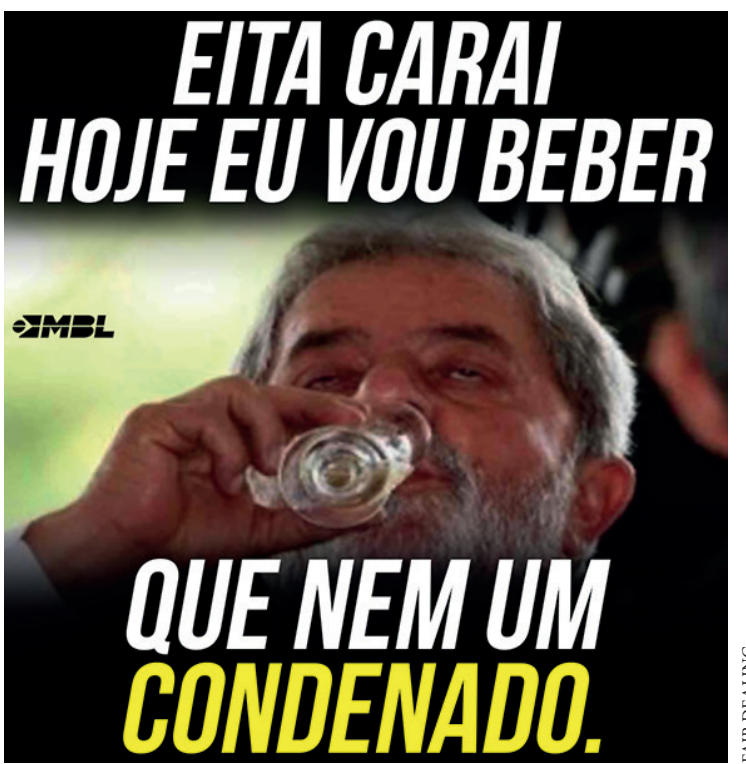

which is in line with its extremist right-wing Christian discourse of defending family values and putting people like Lula in jail. The meme is far removed from the Weberian ideal type of a state that is free of personal relations and personal interests.

These and other memes have deliberately damaged Lula's image and have discredited attempts at humanizing and recognizing the poor population that Lula represents politically, biographically and symbolically. Therefore, these memes can be best understood as a form of iconoclasm. ${ }^{7}$ Circulating the memes on platforms such as Facebook transforms them into a performance on social media, with its ambiguous boundary between private and public. As Latour (1997) points out, the destruction of an image or object immediately implies the production of a new image or object, in this case, one that dehumanizes and criminalizes Lula as well as the poor people he stands for.

\section{Contested class positions}

The memes addressed in this article reflect how poverty and inequality in Brazil have changed dramatically over the past 20 years and how the lines that mark class dis- 
https://data.oecd.org/gdp real-gdp-forecast.htm. For a critical historical analysis of GDP, see Fioramonti (2013).

Bähre, E. 2002. Witchcraft and the exchange of sex, blood, and money among Africans in Cape Town, South Africa. Journal of Religion in Africa 32(3): 300-334.

Comaroff, J. \& J.L. Comaroff 1999. Occult economies and the violence of

abstraction: Notes from the South African postcolony. American Ethnologist 26(2): 279-303.

Fioramonti, L. 2013. Gross domestic problem: The politics behind the world's most powerful number. London: Zed Books.

Kerstenetzky, C.L. et al. 2013. Padrões de consumo e estilos de vida da 'nova classe média'. In $A s$ classes sociais no Brasil contemporâneo, no $37^{\circ}$. Encontro Nacional da ANPOCS, Águas de Lindóia, Setembro de 2013.

Klein, C.H. et al. 2018. Naming Brazil's previously poor: 'New middle class' as an economic, political, and experiential category. Economic Anthropology 5(1): 83-95.

Latour, B. 1997. A few steps toward an anthropology of the iconoclastic gesture. Science in Context 10(1): 63-84.

Lavinas, L. 2017. Takeover of social policy by financialization. London: Palgrave Macmillan US

Lima, M.S. et al. 2018. Bolsonaro applauded by Brazilian business as viable president. Bloomberg, 18 July. bloomberg.com/ news/articles/2018-07-17/

ex-army-captainapplauded-by-brazilindustry-as-viablepresident.

Medeiros, M. et al. 2015. O topo da distribuição da renda no Brasil.

Preimeiras estimativas com dados tributários comparação com pesquisas domiciliares, 2006-2012.

DADOS-Revista de Ciêncas Sociais 58(1): 24-27.

Meyer, B. 2007

Pentecostalism and neoliberal capitalism: Faith, prosperity, and vision in African PentecostalCharismatic Churches. Journal for the Study of Religion 20(2): 5-28.

Neri, M.C. 2012. A nove classe media: O lado brilhante da base da pirâmide Sào Paulo: Saraiava. tinctions have blurred. From 1992 to 2014, Brazil went through a period of economic growth. ${ }^{8}$ When the PT came to power in 2003 and Lula became president, the government set up a range of welfare programmes to alleviate Brazil's deepest poverty. These welfare programmes tried to ensure that economic growth would not only benefit the country's elite and middle class. They were set up to distribute part of the nation's wealth to the many Brazilians living below or on the poverty line. They were intended to alleviate some of the deepest economic and racial inequalities in one of the world's most unequal countries.

Under Lula's administration, the government set up cash transfer programmes for the poor, with Bolsa Família being the most wellknown among these. Established in 2009, Bolsa Família provided small but crucial cash transfers to families living below the poverty line, and improved the living conditions of over 10 million Brazilians. The government also established and expanded other programmes, such as Fome Zero (est. 2003) to fight hunger, Minha Casa Minha Vida (est. 2009) to provide basic housing, and Universidade para Todos (est. 2004) to increase the number of black and poor students in higher education institutions.

There is disagreement about the extent to which poverty was alleviated and the consequences it had for Brazil's class structure. Neri (2012) estimates that from 2003 to 2016 , poverty fell by more than 55 per cent and that approximately 30 million Brazilians escaped poverty by becoming the country's 'new middle class'. Other studies have also found that poverty decreased, but conclude that Neri's study overestimated upward mobility (Kerstenetzky et al. 2013; Klein et al. 2018; Medeiros et al. 2015). While Kerstenetzky et al. (2013) agree that poverty was nearly halved between 2003 and 2011, they argue that living conditions were still too precarious to warrant the use of the term the 'new middle class'. For these reasons, Klein et al. (2018) characterize this group as the 'previously poor'.

Several studies point out that upward mobility was too fragile to be defined as middle class or even lower middle class (Kerstenetzky et al. 2013; Lavinas 2017) and that Neri's definition of class focused too strongly on income and material wealth and thus oversimplified class experience (Klein et al. 2018: 87; see also Souza 2017). Although Brazil's economic growth and welfare programmes removed millions of households from poverty, their living conditions were still very fragile. According to Kerstenetzky et al. (2013) this was especially due to a lack of affordable healthcare. Dealing with illnesses meant that high medical costs, long waiting lists for treatment and inadequate medical facilities could quickly cause families to fall back below the poverty line again. They also argue that transportation costs could render some people particularly vulnerable economically. It is quite common for workers to have to commute up to four hours a day and spend a considerable amount of their income on public transport (Kerstenetzky et al. 2013).

During these years, Brazil's fiscal policy increased consumer debt, but investments in healthcare and affordable transportation lagged behind (Lavinas 2017). Upward mobility was limited and fragile because it was so consumer-oriented (Kerstenetzky et al. 2013; Klein et al. 2018; Lavinas 2017). A study conducted in several Brazilian cities found that 'the strongest correlate of reported upward economic mobility since 2003 was the presence of a freezer in the household' (Klein et al. 2018: 89). The 'previously poor' also adopted other 'middle-class' consumption patterns. Tens of millions of Brazilians could, for the first time ever, take part in a lifestyle that until then had been reserved for the middle class, not for poor people like Lula. One can define the purchase of a mobile phone, hanging around at a shop- ping mall or travelling by aeroplane as superficial or as the wrong kind of consumer-oriented class position that is insufficiently anchored in citizenship rights. However, for many Brazilians, volatile and debt-financed consumption was the hallmark of upward mobility and the aspiration of a dignified life which included a house, a mobile phone and someday maybe even a good education and health insurance.

In Brazil, inequality cannot be reduced to the economic aspects of class alone (Souza 2017). Consumption is not only about distinguishing class according to lifestyle. It is also a political act that challenges symbolic and spatial boundaries. Pinheiro-Machado and Scalco's (2013, 2014) ethnography about young, poor people in Brazil, carefully examines the significance of consumption in rolezinhos, which roughly translates as 'taking a little walk'. The word is derived from the expression 'dar um rolê', meaning going for a walk. In this specific context, rolezinhos occurred when groups of young people from outlying urban neighbourhoods went to shopping malls to hang around. The groups could be made up of just a few or up to hundreds of youngsters who, in the eyes of those who did not want them there, occupied the shopping malls. The youngsters would purchase items from fancy stores, despite their precarious financial situations, or if they could not afford anything, they would stroll around and hang around at the mall, to the great dismay of the wealthier shoppers.

Rolezinhos became an important phenomenon in Brazil and was widely reported in the media, particularly in 2014. Sometimes, the youngsters were brutally removed by mall security, highlighting the view that they did not belong there. The authors (Pinheiro-Machado \& Scalco 2014) use the case of the rolezinhos to explain how poor people visiting malls and luxury brand shops defied consumption patterns and challenged Brazilian class and its racial and spatial segregation. According to PinheiroMachado and Scalco $(2013,2014)$ consumption rituals offer important insights into political and economic change in Brazil, where upward social mobility policies are consumer-oriented.

By showing how poor people found different ways to discuss politics and be political in everyday life, PinheiroMachado and Scalco present an alternative analysis to those who argue that the changes that occurred in Brazil's social classes were very fragile. The rolezinhos was not only about acquiring cultural capital and desired consumer items as a sign of upward mobility and distinction. It was also a way of contesting the inequalities that young people from poor neighbourhoods experience in everyday life (Pinheiro-Machado \& Scalco 2013, 2014).

Around 2015, Brazil's economic growth came to a halt and the country descended into a recession unlike any it had experienced since the end of the military dictatorship (1964-1985). This downturn exposed the vulnerability of people's class positions. Even professionals, such as the businessman Roberto, were worried that their lifestyles were unsustainable and that their children's future could be bleak. The recession blurred the boundaries of consumer-oriented class positions even further.

Several of the people we spoke to expressed anger at the Brazilian tax system. They claimed that they paid taxes without receiving anything in return, while ignoring or downplaying how wealthier people benefit from government subsidies and tax exemptions for higher education and healthcare. A lawyer, who was very pleased about Lula's conviction, told us: 'I went to private university [without government support], my daughter goes to a private school [without government support] and I have to pay for private healthcare insurance [without government support]. But the streets are 


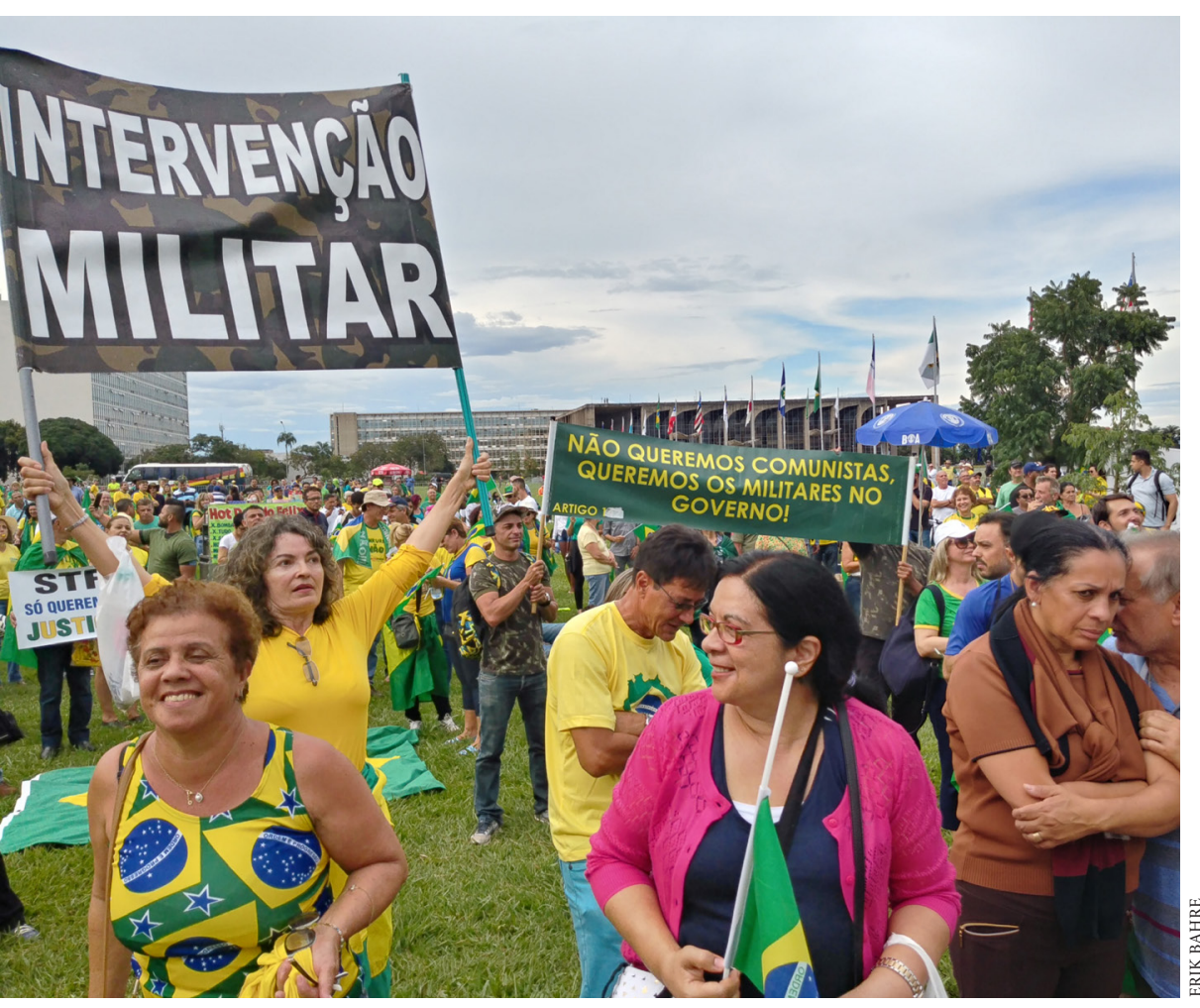

Fig. 8. Anti-Lula demonstration at the Supreme Court, Brasilia, 4 April.

Pinheiro-Machado, R. \& L. Scalco 2013. Sobre bondes de marca: Consumo e rituais entre jovens de baixa renda na cidade de Porto alegre. In C. Rial \& S. Rúbia Silva (eds) Consumo e cultura material: Perspectivas etnográficas, 131-154 Florianópolis: Editora da UFSC.

- \& - 2014. Rolezinhos: Marcas, consumo e segregação no Brasil. Revista de Estudos Culturais EACH USP 1: 1.

— \& T.V. Maia 2018 As múltiplas faces do conservadorismo brasileiro. Revista CULT 234: 26-31.

Rose, G. 2001. Visual methodologies: An introduction to the interpretation of visual materials. London: SAGE Publications.

Souza, J. 2017. A elite do atraso - Da escravidão à Lava Jato. Rio de Janeiro: Leya Editora.

Taussig, M. 1980. The devil and commodity fetishism in South America. Chapel Hill: University of California Press.

Thoden van Velzen, H.U.E. 1997. Dramatization: How dream work shapes culture. Psychoanalytic Review 84(2):173-188

van Dijk, T. 2017. How

Globo media manipulated the impeachment of

Brazilian President Dilma Rousseff. Discourse and Communication 11(2): 199-229. in bad condition, with many potholes. You pay taxes and you get nothing in return. What kind of citizenship is this? It is the state's obligation to provide health and education, but they don't do it!'

On 4 April 2018, we went to a demonstration in front of the Supreme Court. That day, the Supreme Court decided that Lula could not await the outcome of his appeal outside jail, which led to his imprisonment a few days later. The demonstration that we attended was against Lula. There were approximately 1,000 to 2,000 protesters and a large truck with a sound system and banners saying things like 'Clean up Brazil'. On top of the truck was someone dressed in a costume depicting Lula in a grey, striped prison uniform with the number 13-171. The first number is the official code of Lula's Worker's Party and the second number refers to a law against embezzlement

Most of the speakers on top of the truck were speaking on behalf of an organization, but did not reveal their personal names. An anonymous member of the Movimento Brasil Livre said with great emotion: 'If the Brazilian people do not wake up now, a military intervention will have to come!' Another speaker, who did not reveal his name or any affiliation to an organization said: 'Nobody here got out of poverty because of Lula. [Crowd cheers] Nobody here got an education because of Lula. [Crowd cheers] Nobody here travels by plane because of Lula. [Crowd cheers] Today the airports look like bus stations. We need to lock up the rapists, the drug criminals, the crackheads. We need to lock up Lula. They do nothing for this country. Clean up Brazil!' [Crowd cheers] Speeches and applause and cheering went on for hours.

At this event, it became clear once again how consumption is political and lies at the heart of the deep-seated inequalities in Brazilian society. As Pinheiro-Machado and Scalco $(2013,2014)$ have shown, people were angry that the poor visited shopping malls and luxury shops, and were going to universities and frequenting airports. This anger was what fuelled the political smear campaign against Lula.

Pinheiro-Machado and Scalco's (2013) work can again be evoked to say that consumption was a means of social inclusion, because it defied segregation and prejudice against poor people. Because segregation is intrinsically part of Brazil's social structure, when poor people achieve some level of inclusion, they attract added discrimination. Middle-class and rich people do not like sharing 'their' space (such as fancy malls in the case of the rolezinhos, or airports and universities as quoted in the demonstration) with poor people. In the current political and economic environment, references to cachaça and to visiting airports and shopping malls are deeply political.

As Souza (2017) has also pointed out, sentiments such as these are crucial to understanding the humiliation of Lula as a representative of those framed as the undignified poor. The anger against a class that has, at least to some extent, achieved a consumer lifestyle that some say does not belong to them, is incited by memes on social media and resonates with the right-wing political movement that presidential candidate Bolsonaro stands for.

The humiliation of Lula and the anger directed at him also needs to be understood in the light of how people selfidentify. Although Brazil remains one of the most unequal countries in the world, class positions have changed over the past 20 years. The consumer styles that distinguish class positions have blurred. Economic growth, along with government welfare and monetary policies, has allowed millions of poor people to adopt a consumer-oriented lifestyle that they had been excluded from before.

Their fragile upward mobility was to some extent hidden by consumerism. Having a mobile phone or visiting airports and shopping centres is clearly visible. It is much harder to see if someone has good health insurance, a steady job or spends hours every day on public transport. This is what makes the consumption patterns appropriated by the poor so unsettling. 'They' have moved closer to 'us' by 'invading' spaces such as airports. Thus, when the deepest economic recession in over 30 years hit Brazil, it left many feeling exposed and vulnerable, further blurring their sense of being securely distinct from the poor. The people who circulate and support the memes discussed here create a sense of unity based on defining what they are not - namely, the 'popular class' and the inhumanity and immorality that is associated with being poor.

The iconoclasm of Lula reveals the anguish of economic mobility that blurs the lines between 'us' and 'them'. The memes on social media counter this blurring by creating a symbolic line between 'us' - the 'middle class', the 'good people' (pessoas do bem), who pay taxes supposedly without benefits - and 'them' - the poor, who are depicted as drunkards, undignified, the masses who receive money from the government in exchange for giving political support to the PT. The iconoclasm marks these distinctions and provides an outlet for expressing a contempt and fear of poverty in a country where, due to global economic changes and national politics, class distinctions have become more vulnerable.

The international discourse against corruption legitimizes the anger and hatred against Lula and the tens of millions of poor Brazilians that he represents. He represented them in the past as Brazil's president and leader of the largest political party. He represented and still represents them because of his biography: a poor and uneducated Northeasterner who broke his way into the nation's political elite, and who should be removed from that elite, just as the poor should stop going to airports and shopping malls.

For millions of Brazilians, Lula is the icon that encapsulates hope for the poor, the hope of being recognized as fellow human beings - a recognition based on appropriating the consumer items of a privileged class. The memes are attempts to desecrate that icon. The Brazilians circulating and supporting these memes are saying that Lula must leave - he must go back to the prison of poverty, back to zombie life. 